Nuntius Antiquus, Belo Horizonte, Universidade Federal de Minas Gerais, ${ }^{0}$ 1, junho de 2008, Brasil

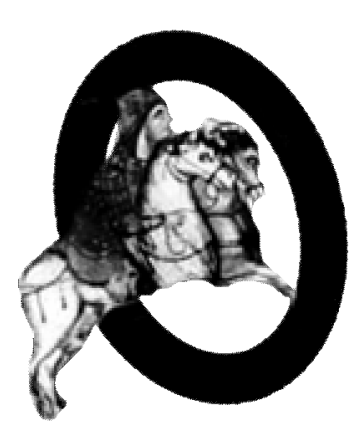

\title{
Filinto Elísio, tradutor de Lucano: estudo introdutório, edição crítica e notas de uma versão da Farsália (I 1-227)
}

\author{
Brunno V. G. Vieira \\ UNESP/ Araraquara \\ e-mail: brvieira@fclar.unesp.br
}

\begin{abstract}
The article presents a critical edition of the first 227 verses of Lucan's Pharsalia, translated into Portuguese by Filinto Elísio, pseudonym of Francisco Manuel do Nascimento (1734-1819), and shows the translation conceptions underlying the work of this influential poet and translator; it is meant to be a contribution to discussions on the literary translation of classical texts.

KEYWORDS: Filinto Elísio; Lucan; translation theory; translation history; literary translation.
\end{abstract}




\title{
Filinto Elísio, tradutor de Lucano: estudo introdutório, edição crítica e notas de uma versão da Farsália (I 1-227)
}

\author{
Brunno V. G. Vieira \\ UNESP/ Araraquara \\ e-mail: brvieira@fclar.unesp.br
}

\begin{abstract}
The article presents a critical edition of the first 227 verses of Lucan's Pharsalia, translated into Portuguese by Filinto Elísio, pseudonym of Francisco Manuel do Nascimento (1734-1819), and shows the translation conceptions underlying the work of this influential poet and translator; it is meant to be a contribution to discussions on the literary translation of classical texts.

KEYWORDS: Filinto Elísio; Lucan; translation theory; translation history; literary translation.
\end{abstract}

Filinto Elísio, pseudônimo de Francisco Manuel do Nascimento (1734-1819), foi um dissidente da Arcádia Lusitana e, em sua obra, vasta e multifacetada, pode-se encontrar um considerável volume de traduções de poemas da Antiga Roma entre as quais figura a versão da Farsália que apresentamos aqui.

O estilo duro e de viés arcaizante de Filinto foi admirado por Almeida Garrett (1799-1854), que no seu primeiro livro, Lírica de João Mínimo, dedica-lhe dois poemas. O próprio Garrett no prefácio desse livro por várias vezes opõe o estilo de Filinto, rotulado por ele de "filintista", ao gosto da clareza e fluência dominante no Arcadismo português que o autor de Camões atribui à "seita elmânica" ou aos “elmanistas”, em evidente alusão a Elmano Sadino, pseudônimo de Bocage.

Outro pilar do romantismo português, o poeta Antônio Feliciano de Castilho, identifica essa mesma divergência estilística ${ }^{1}$ e, embora confesse coadunar com os elmanistas, não deixa de devotar este belo elogio ao legado estilístico de Filinto: "Foi um mártir da religião de nossa língua [...] com o excessivo das jóias com que a arriou, deixou-a afetada, e menos matrona grave do que bailarina de corda; sim habilidosa e leve, mas dengosa e presumida". 2

Ora, essa dicção que fez de Filinto um autor reverenciado pelos poetas do Romantismo está inextricavelmente relacionada ao seu trabalho de tradutor, como já observara Castilho ao chamar atenção às jóias com que ele arriou nossa língua. $\mathrm{Na}$

\footnotetext{
${ }^{1}$ Cf. de Castilho, A. F. A primavera. 2a . ed. Lisboa: Bulhões, 1837, p. 132: No tempo em que eu cursava meus estudos na Universidade de Coimbra, [...] duas seitas de escrever se contavam; a cada uma das quais não faltavam admiradores [...]. Os livros em que uma juramentava os seus adeptos eram Gessner e Bocage; Filinto era o Alcorão da outra.

${ }^{2}$ Cf. de Castilho, op. cit., p. 152.
} 
Carta a Brito (1790), Filinto defende um modo sui generis de enriquecimento da língua portuguesa, fugindo do galicismo então em voga:

Nós hoje, se prezamos levantar-nos ao grau de glória a que éramos subidos Trilhemos senda que ampla nos abriram Nossos maiores no apurar do engenho. Eles da grega língua, e da latina tomaram cabedais, com que adornaram De garbo e de melindre a Lusa fala. ${ }^{3}$

Como dessas palavras se pode interpretar, o entendimento de língua e estilo em Filinto se estende naturalmente às suas concepções tradutórias, uma vez que a tradução de latinos como Horácio, Lucano e Sílio Itálico, levada a cabo por ele, é um exercício ligado ao enriquecimento ou nas palavras dele "aperfeiçoamento" da língua materna. ${ }^{4}$

Na presente versão de Lucano, podemos perceber a materialização desse ideário estilístico e tradutório presente, seja no constante emprego de arcaísmos, latinismos e palavras cognatas, seja pelo acúmulo de hipérbatos, procedimentos que refletem uma marcada tendência a um literalismo tradutório tanto no nível lexical, quanto no sintático. No que toca à abordagem tradutória, aliás, Filinto também fez escola, se pensarmos na influência cabal que teve em tradutores como Manuel Odorico Mendes, que se autodeclarava seu discípulo, ${ }^{5}$ e a sua concepção tradutória é convergente com modernas idéias de tradução literária como aquela expressa por Walter Benjamim no seu ensaio seminal A tarefa-renúncia do tradutor. ${ }^{6}$

\footnotetext{
${ }^{3}$ Cf. Filinto Elísio. Obras completas de Filinto Elísio. Ed. F. Morais. Braga: APPACDM, 1998. Vol. 1, p. 60.

${ }^{4}$ Ele dirá nessa mesma Carta: $O$ modo de aperfeiçoar a língua materna é enxertando nela o precioso das outras (cf. Filinto Elísio, op. cit., 1998, p. 63).

${ }^{5}$ Esse discipulado é declarado pelo próprio Odorico: Dentais dorsiduplos em vez de "que têm dois dorsos" ou "de dois lados reforçados": discípulo de Ferreira, de Camões, de Filinto, não recuo à vista de uma palavra composta, mais curta e enérgica (nota ao passo I 172 das Geórgicas, grifo nosso). Ao comentar a tradução filintista dos Mártires de Chateaubriand, Odorico reserva ao tradutor o seguinte elogio: Francisco Manuel, quanto à graça da linguagem, na sua tradução me parece preferivel ao mesmo autor; e a obra, apesar de não poucas incorreções, considero-a como o modelo do seu genero: não conheço um tradutor poeta que tanto me agrade, em língua nenhuma (nota à Eneida III 369-611 592-634, grifo nosso).

${ }^{6}$ O elogio a uma tradução, sobretudo na época de seu aparecimento, não é poder ser lida como um original em sua língua. Antes, o significado da fidelidade garantida pela literalidade é precisamente que se expresse na obra o grande anelo por uma complementação entre as línguas. A verdadeira tradução é transparente, não encobre o original, não o tira da luz; ela faz com que a pura língua, como que fortalecida por seu próprio meio, recaia ainda mais inteiramente sobre o original. Esse efeito é obtido sobretudo por uma literalidade na transposição da sintaxe, sendo ela que justamente demonstra ser a palavra - e não a frase - o elemento originário do tradutor [cf. Benjamin, Walter. A tarefa-renúncia do tradutor. Tradução de S. K. Lages. In: Heidermann, W. (org.). Clássicos da teoria da tradução. Florianópolis: EDUFSC, 2001, p. 209].
} 


\section{Onuntius antiquus}

Diante da pujança e da permanência desse poeta-tradutor, desejamos com o presente artigo divulgar tanto a obra lucaniana - objeto de nossa recente tese de doutorado -, quanto o profícuo e ainda atual pensamento tradutório filintista.

As duas primeiras notas de rodapé da tradução contextualizam e justificam a escolha do original e a motivação do trabalho tradutório, sendo feitas uma no começo da sua empreitada, outra no final. Devido ao caráter prefacial dessas anotações optamos por transpô-las para este estudo introdutório, uma vez que ensejam uma apresentação de Lucano e de sua obra. Diz Filinto:

Muitos me criminaram, de malograr o estudo e o tempo, em dar as honras de versão a um poeta tão desacreditado como Lucano. "Não havia aí Virgílio e Homero; que têm por si todos os votos? Os votos mesmos dos que nunca os leram?" Que muito há já, que na fé alheia, e sem conhecimento da causa, se liberalizam os encômios e os vitupérios. Mas leiam este poema esses desdenhosos; e se amam formosura varonil, se estilo arrebatado e ardente, se amam sentenças vivas e profundas, pinturas que nos olhos ferem, em Lucano as encontrarão. Nem, porque Virgílio tomou no Parnaso Latino o primeiro assento, se hão de eclipsar Ovídio, Lucano e Sílio Itálico. Nem todos os vates Lusitanos Camões foram; e todavia a Ulisséia, a Málaca conquistada, o Afonso Africano granjearam entre os doutos estimação. Quanto se não ufanariam os críticos tais, de haver composto, no verdor de 27 anos esta Farsália.

Comecei esta tradução, pouco tempo depois de ter chegado a Paris: mas duas razões me atalharam de a continuar, a $1^{\mathrm{a}}$. os desmesurados e tão indignos encômios, que a um tirano dá; $2^{\mathrm{a}}$. as voluntárias e malmerecidas mortes dos Opitergines, ${ }^{7}$ sem contar os defeitos, que os críticos assacam a esse poeta. Confesso que aplicaria com mais lucro o meu ócio em traduzir a Eneida; mas esta já se achava traduzida por J. F. Barreto, que, se não deitasse ao seu engenho o grilhão dos consoantes teria quase corrido parelhas com Virgílio: mas tal qual ela é, merece ainda grande preço, e só podem criticá-la os que não possuírem assaz de cabedal para a empreenderem. As Metamorfoses de Ovídio já o Sr. Barroco, já outro vate Almeno as tinha começado. Só me restava Sílio Itálico e Lucano. Comecei a Farsália. Outro virá depois, se tiver anos de vida, sossego, e pachorra.

Pode-se ver o tom entusiasmado de Filinto num primeiro momento quando ele insiste no digno posto que ocupam as obras menores na tradição literária e identifica um dado crucial na recepção da Farsália: os encômios e vitupérios virem não pela leitura do próprio poema, mas por testemunhos indiretos. Na segunda nota, contudo, fica nítida

\footnotetext{
${ }^{7}$ Cf. Lucanus. De bello ciuili. Cum Hug. Grotii, Farnabii notis integris et uariorum selectissimis. Londini: J.F. Dove, 1818, IV 461ss.
} 
a decepção "republicana" e "liberal" do $\operatorname{tradutor}^{8}$ com a visão monarquista do autor latino. Além disso, Filinto dá a entender que sua escolha da Farsália se deve ao fato de já estarem Virgílio e Ovídio traduzidos ao português, muito embora ele se dê por satisfeito de ter começado a tradução da Farsália convocando-nos, futuros tradutores, com mais tempo e paciência...

A Fársália é uma epopéia dedicada à Guerra Civil entre César e Pompeu escrita por Lucano no séc. I de nossa era sob o principado de Nero. O trecho traduzido por Filinto é o início do livro primeiro da obra, dedicado às causas da guerra e aos primeiros atos de hostilidade de César.

Passada a Conjuração de Catilina em 63 a. C, Roma vivia um período de frágil paz interna (concordia discors, "discorde aliança" - v. 127), que veio a se consolidar em 60 a.C. com a formação do primeiro triunvirato, uma coalizão entre os generais Crasso, César e Pompeu. A esses dois últimos, além do pacto político, unia um certo grau de parentesco já que Júlia, filha de César tinha contraído matrimônio com Pompeu no ano de 59 a.C. Transcorridos alguns anos, esse "nó do império", que era o primeiro triunvirato, veio a se fragilizar seja com a morte de Júlia (v. 145-156) em 54 a.C., seja com a de Crasso (v. 129-41), em 53 a.C. Como nenhum dos dois restantes aceitava ser o segundo em Roma (v. 161-3), instaura-se a Guerra Civil: de um lado está Pompeu, confiado nas suas vitórias no Oriente, Egito e Espanha, do outro, César, animado pelas vitórias na Gália. Na cidade de Roma, com o favor do cônsul Marcelo e do senador Catão, o Senado numa conturbada sessão proíbe César, que estava ausente da cidade, de se tornar cônsul, mesmo que os tribunos favoráveis a ele, entre os quais Curião, tentassem a aprovação disso a todo custo. Diante desse impedimento, César cruza o Rubicão com suas tropas (v. 240-92).

A tradução desse início da Farsália, que apresentamos aqui, foi elaborada, segundo as indicações de Filinto, ${ }^{9}$ pouco tempo depois do seu exílio em Paris em 1778. No estabelecimento do texto, tomamos por base a edição das Obras Completas de Filinto Elysio (vol. 11), de 1819, publicada em Paris pela casa editora A. Bobée, e acolhemos as correções que aparecem na edição póstuma das Obras de Filinto Elysio, (vol. 10), de 1838, editada pela Typographia Rollandiana em Lisboa. Infelizmente não tivemos acesso ao volume 10 da moderna reedição levada a cabo em Portugal por Fernando Moreira em 2001, da qual compulsamos apenas os seis primeiros volumes,

\footnotetext{
${ }^{8}$ Lembremos que, à época da tradução, Filinto respirava os ares da Revolução Francesa.

${ }^{9}$ Cf. supra p. 3: Comecei esta tradução, pouco tempo depois de ter chegado a Paris.
} 
inclusive sua primorosa introdução.

Intentamos, quanto nos foi possível, oferecer uma edição crítica marcando as variações entre as edições e emendando alguns erros tipográficos evidentes. Respeitamos a pontuação original (exceto em alguns casos indicados em nota) e procedemos à atualização ortográfica resguardando possíveis vulgarismos de grafia (como "permeiadas" - v. 153), mas também as síncopes e elisões características da prosódia lusitana (“c'o, té, qui, stragos, asp'ra”, etc.). Adequamos o uso das maiúsculas ao nosso atual modelo.

Por meio de comparações entre as edições do texto latino de Lucano, publicadas entre os séculos XVII e XVIII, conseguimos determinar o editor do texto seguido por Filinto: trata-se da edição de Hugo Grotius com notas e comentários de Farnabius que foi publicada primeiramente em meados do séc. XVII e que se tornou uma edição prestigiada, sendo reeditada inúmeras vezes. ${ }^{10} \mathrm{~A}$ começar pelo argumento do editor renascentista Sulpitius Verulanus, constante em Grotius, a pontuação de Filinto segue de perto a dessa edição, além do que algumas lições exclusivas de Grotius encontram-se ali traduzidas. ${ }^{11}$

Ao cotejar o texto de partida e o texto de chegada notamos que Filinto traduz de modo bastante minucioso e preciso, quase sempre palavra por palavra. Sua leitura é atenta e chega, nos passos mais difíceis, à clara consulta das notas da edição farnábiogrotiana. ${ }^{12}$ Têm lugar cativo nessa versão lucaniana a concisão e os hipérbatos, duas pedras de toque do estilo filintista, como ele próprio teoriza:

(Sobre a concisão) Os escritores, que dizem pouco em muito, folgam de circunlocuções. Eu que sou preguiçoso de escrever, quisera (se coubesse no meu fraco talento) que cada palavra encerrasse um período. Assim quanta mais escritura forrar posso, mais mão lanço de termos compreensivos de ampla significação; modernos, antigos, latinos, estrangeiros, tudo entra no saco, tudo me faz conta, logo que sejam curtos, expressivos e sonoros. ${ }^{13}$

(Sobre os hipérbatos) Quantas vezes, quantas/ O intrépido poeta arrisca o enleado/ Hipérbato, que embaça a inteligência,/ À prima

\footnotetext{
${ }^{10}$ Tivemos acesso a uma reedição londrina de 1818 (cf. Lucanus, op. cit., 1818).

${ }^{11}$ São de estabelecimento exclusivo de Grotius: astringit Scythicum glaciali frigore pontum! (Farsália I 18), "e o Cítio mar algema,/ c'os frios gelos"; discindere (I 31), "dar-nos mau fim"; permissum est ducibus (I 120), "aos capitães foi dado"; praestinguens (I 154), "deslumbra” (cf. Lucanus, op. cit., 1818).

${ }^{12}$ Cf. nota de Grotius \& Farnabius aos versos I 31-2, nulli penitus discindere ferro/ contigit: "discindere" - in totum dissipare et quasi delere Romanum imperium, "discindere - dissipar totalmente e quase destruir o Império Romano". O que resultou na seguinte tradução de Filinto (v. 39-40): "que a ninguém coube/ dar-nos mau fim, com ferro, a todos" (cf. Lucanus, op. cit., 1818).

${ }^{13}$ Cf. Filinto Elísio, op. cit., 1998, p. 67.
} 
vista, mas que apraz, namora,/ quando abre todo o senso! $!^{14}$

Os latinismos e o uso de vocábulos antigos são justificados pela premissa da concisão. Fugindo das circunlocuções e procurando uma precisão semântica no texto de chegada, Filinto lança mão dos procedimentos lexicais de empréstimo e de arcaísmos. ${ }^{15}$ Quanto aos hipérbatos percebe-se na explicação de Filinto o gosto e o prazer da obscuridade que o faz um seiscentista, na visão de Lopes e Saraiva, ${ }^{16}$ mas também sentimos nesse recurso uma espécie de decalque de uma figura cara à poesia latina à medida que muitos dos seus hipérbatos buscam uma equivalência com os usados por Lucano. $^{17}$

Nos 227 latinos traduzidos, pudemos detectar uma negligência, justificável, contudo, pela própria concisão filintitista. Por questões de síntese, mas também devido à dificuldade da passagem que trata da morte de Júlia, filha de César (v. 145-9), que oscila entre o tratamento em $2^{\mathrm{a}}$. e $3^{\mathrm{a}}$. pessoas, o tradutor acaba omitindo o nominativo

\footnotetext{
${ }^{14}$ Cf. Filinto Elísio, op. cit., 1998, p. 44.

${ }^{15}$ Cf. v. 2, "jus" de ius; v. 3, "destra" de dextra; v. 6, "roto" de rupto; v. 11, "libra" arcaísmo ao invés de livra (libra<liberare); v. 20, "ringe" de rigens; v. 39, 56, 120, 129, 145, 148, 162, 168, 236, "que" como conjunção causal com o sentido de "porque"; v. 44, "se aparelham" de parantur; v. 46, "Terrígenas", do adjetivo terrigenus, a que o próprio tradutor anota "Titãs"; v. 44, 47, 106 e 166, "numes" e, v. 65, 80 e 263, "númen", de numen, "divindade"; v. 50, "manes", de manes "espíritos ou almas dos mortos"; v. 51, 138, 219, "destroço" arcaísmo com o sentido de "derrota, ruína"; v. 65, "sólio", latinismo de uso poético, de solium, "assento"; v. 66, 92, 103, 192, 218, "orbe" de orbis, "esfera, mundo"; v. 67, "Natura" latinismo usual em Camões e nos quinhentistas; v. 71, "facha" arcaísmo do lat. fascia, ao invés do corrente faixa; v. 72, "sentir-se-á" por "ressentir-se-á", como Camões, "os ventos esta injúria assim sentiram" [Dicionário Caldas Aulete (C. A.)]; v. 72, "axe", de axis, ao invés do corrente "eixo"; v. 73, "libra" de librat, equilibra; v. 103, "estroncado" ao invés de destroncado, por aférese; v. 105, "moles" de moles, "grande massa, grande volume"; v. 111, "liga" com sentido de pacto, aliança; v. 121, "releva" arcaísmo com sentido de "importar, ser conveniente" (C. A. o abona com Camões); v. 126, "empenhou" no sentido de impelir/ compelir; v. 127 e 169, "remanso" do lat. remansio, "pausa"; v. 145, "seva" de saeua, "irada"; v. 147, "diro" de dirus "funesto"; v. 158, "pirático" de piratica; v. 161, "insofrida" verte literalmente impatiens "que não se pode conter"; v. 207, "afundiram" por "afundaram"; v. 225, "quedas" como adjetivo, significando "imóveis", remonta a Camões "agora estando queda, agora andando" (C. A.); v. 236, âmbito de ambitus (cf. nota 61 do próprio Filinto); v. 277, "transcura" neologismo com o sentido de "não cuidar de", provavelmente motivado pelo sintagma por tanti securus uulneris.

${ }^{16}$ Cf. Saraiva, A. J.; Lopes, O. História da literatura portuguesa. $15^{\mathrm{a}}$. ed. Porto: Porto Editora, 1989, p. 687.

${ }^{17}$ Cf. v. 16, "co'esse, que as vossas mãos, sangue, verteram", de hoc, quem ciuiles hauserunt, sanguine, dextrae; v. 34-7, "na de antes populosa,/ hoje crespa de abrolhos, não lavrada/ Hespéria, há muitos anos, e pedindo/ a terra as mãos está", et antiquis ... in urbibus.../, horrida quod dumis multosque inarata per annos/ Hesperia est desuntque manus poscentibus aruis; v. 39-40, que a ninguém coube/ dar-nos mau fim, com ferro, a todos; v. 80-2: "tu és meu númen já; nem, se em meu seio/ te acolho eu vate, invocar trato/ esse deus", sed mihi jam nume: nec, si te pectore uates/ accipiam, Cirrhaea uelim secreta mouentem/ sollicitare Deum; v. 99-102, "a Apolo oposta/ de dous corcéis reger irada a Lua/ por essa obliqua zona, em carro de ébano,/ quererá, como o irmão raiar o dia; v. 221-2, "e as que outrora lavrou com relha dura/ terras Camilo", uma recriação do hipérbato sulcata...passa....rura do texto latino: et quondam duro sulcata Camilli/ uomere, et antiquos Curiorum passa ligones Longa sub ignotis extendere rura colonis; v. 78-9, "do belígero Jano as férreas portas,/ a paz enviada ao mundo inteiro as feche", que recria em português o verso de ouro com hipérbatos ferrea belligeri conpescat limina Iani.
} 
Julia presente no texto latino. Essa escolha tradutória resulta em um truncamento de sentido tal que leva Filinto a lançar mão de três notas de rodapé seguidas (cf. infra notas $40,41,42$ ), sendo que a nota 41 , a nosso ver, reputa à ignorância dos leitores uma possível dificuldade de leitura, quando é a escolha tradutória que trunca o entendimento.

A despeito disso, pela seriedade com que Filinto trata o texto latino, seria justo aplicar-lhe aquela sentença que Voltaire dedicara a Lucano "ele não deve a ninguém nem suas qualidades, nem seus defeitos", mas que o leitor tire suas próprias conclusões a partir da presente edição de seu texto.

\title{
FARSÁLIA \\ DE MARCO ANEU LUCANO
}

\author{
Livro I [1-227] \\ A R G UMEN T O
}

Da guerra as causas diz; como impelido

Da acelerada cólera, atravessa

César do Rubicon a veia, e investe

Com sobrecenho a Rímini vizinha,

E como acolhe os da assombrada Roma,

Expulsados tribunos: para guerra

Os seus anima; o fiel socorro chama

Das coortes. Jaz Roma em frio susto.

Medroso vai Pompeu, medrosa a Cúria.

Prodígios surgem; dão resposta os vates.

Guerras mais que civis, ${ }^{18}$ no Emátio campo,

$\mathrm{O}$ jus dado à maldade canto, e o povo

Poderoso, que contra entranhas suas

Houve empregado a vingadora destra.

Co'as forças juntas do abalado mundo, ${ }^{19}$

\footnotetext{
${ }^{18}$ Necessitariam muitos lugares desta versão severíssimas emendas: mas nem um Lucano tenho de meu. Os que o tiverem emendem a versão e lho agradecerei como assinalado favor (as notas do editor serão indicadas pela sigla N.E., as demais notas são de Filinto Elísio).
} 
Hostes parentas, roto o nó do império,

Para o total desastre, combateram:

Pendões contra pendões, águias contra águias,

Dardo no encontro hostil dardo ameaça.

Que furor, cidadãos, que solto ferro

Libra a odiadas nações o sangue Lácio;

Quando arrancar à ufana Babilônia

Os Ausônios troféus, melhor cumpria?

Quando os manes de Crasso inultos erram,

Guerras travais, indignas de triunfo!

Co'esse, que as vossas mãos, sangue, verteram ${ }^{20}$

Que assaz terra e assaz mar ganhado fora,

Onde o sol surge e acolhe a noite os astros!

Onde a pino flameja e ferve o dia,

Ou ringe a neve e o Cítio mar ${ }^{21}$ algema,

C'os frios gelos, que o verão não solta!

Já o bárbaro Aráxes, já os Seres

Curvariam c'o jugo, e quanto povo

Vê o Nilo de incógnita nascente:

Então, Roma, quando hajas sotoposto

Inteira a redondeza a teu império,

Já que a nefanda guerra anelas tanto,

Volta armas contra ti, e hás inimigos.

Agora, que, nas Ítalas cidades,

Destroçados os tetos, as paredes

Pendem, e as derribadas cantarias

Das muralhas, desmanteladas jazem;

Guarda as casas não têm, raro $^{22}$ vagueia

O morador, na de antes populosa,

Hoje crespa de abrolhos, não lavrada

\footnotetext{
${ }^{19}$ Em relação ao texto latino, este verso e o próximo estão invertidos (N.E.).

${ }^{20}$ Novamente, em relação ao texto latino, este verso e o próximo estão invertidos (N.E.).

${ }^{21}$ Como seria fácil o espraiar-se em notas quem abundasse em livros! Eu, ainda que o quisera, não os tenho. Lá os há por esse mundo; a eles recorram os que não sabem.

${ }^{22}$ Reduzida a cidade a poucos moradores.
} 
Hespéria, há muitos anos, e pedindo

A terra as mãos está, que lhe negamos.

Não foi Pirro feroz, não foi Haníbal

Quem 'stragos tais nos fez: que a ninguém coube

Dar-nos mau fim, com ferro, a todos: - jazem,

Por mão civil, profundas as feridas.

Mas se outra via os Fados não tomaram

Para a vinda de Nero; ${ }^{23}$ eternos reinos

Só a grão preço aos numes se aparelham:

Nem ao Troante ${ }^{24}$ seu bem serve o Olimpo,

Se aos Terrígenas crus ${ }^{25}$ não dá combate.

Cessa, oh numes, o agravo nosso; os crimes,

As maldades, com prêmio tal, contentam. ${ }^{26}$

Encha Farsália as lúgubres campinas,

Cevem-se em sangue os manes de Cartago,

Veja Munda o nosso último destroço:

Co'as fadigas de Módena, co'a fome

De Perúsia, estes fados, César, medrem,

C'os baixéis, que submerge asp'ra Leucate,

E no Etna ardente, co'a servil batalha:

Que muito às civis armas deve Roma,

Se tu lhe és prêmio e fim. Quando tardio

Corrido o giro ${ }^{27}$ teu, aos astros subas,

Pospondo a terra aos céus, te acolha o Olimpo,

Com gosto em seu alcáçar, ou já prezes

$\mathrm{O}$ cetro menear, ou nas carroças

Flamígeras de Febo ir assentado

Com vaga tocha alumiando o mundo,

Do permutado sol desassustado: ${ }^{28}$

\footnotetext{
${ }^{23}$ Injustíssima lisonja! Nero a pagou pouco depois com a morte do lisonjeiro. Quão felizes os povos, se igual prêmio às lisonjas os reis dessem!

${ }^{24}$ Júpiter trovejador.

${ }^{25}$ Os Titãs, filhos da Terra.

${ }^{26}$ Corrigiu-se aqui a vírgula da edição de 1819 por este ponto-final na edição de 1838 (N.E.).

${ }^{27}$ De teus anos.
} 
Númen não há que o sólio te não ceda;

E a qual deus queiras ser, ou do orbe o mando

Ponhas, Natura o franco jus te entrega.

Mas não na Arctoa plaga assento escolhas,

Nem onde o ardor afunda a meta austrina,

D'onde, astro oblíquo, a tua Roma influas. ${ }^{29}$

Se uma facha do imenso etéreo oprimes,

Sentir-se-á o axe do pendor: no meio

Do empíreo o peso libra a um pólo e outro;

Sereno o ar seja, nesse espaço, e limpo:

Que entre César e nós não vaguem nuvens.

Então a humana prole as armas pondo, ${ }^{30}$

Os seus úteis consulte e mútua se ame.

Do belígero Jano as férreas portas,

A paz enviada ao mundo inteiro as feche.

Tu és meu númen já; nem, se em meu seio

Te acolho eu vate, invocar trato ${ }^{31}$

Esse deus, que os arcanos move em Cirra,

Nem de Nisa arredar Baco. Assaz forças

Para os romanos versos dar-me podes.

Leva-me a mente a desferir as causas

de tão grandes sucessos. - Cena imensa

se me abre. Quem o povo insano, às armas

impeliu? Quem a paz lançou do mundo?

Cortou Fado invejoso o fio às Ditas:

Negado lhe é durar. - Bem, que é supremo!

Quanto o peso é maior mais grave é a queda,

Nem já se tinha Roma! Assim, deste orbe

O enlace desatado, essa hora extrema,

\footnotetext{
${ }^{28}$ Tão certa e segura está, que tomando tu as rédeas do carro Apolíneo não lhe virá de ti incêndio algum, como de Faeton lhe veio. (N.E.) O tradutor coloca equivocadamente o "desassustada" como expansão adjetiva de "tocha", já que no original timentem está ligado a tellurem, "mundo", emenda-se esta falha de revisão, trocando o gênero do adjetivo "desassustada" por "desassustado".

${ }^{29}$ Falava de siso Lucano a Nero? Ou estava dele escarnecendo?

30 "Pondo" por "depondo". O positivo pelo composto.

${ }^{31}$ Para soar um decassílabo, é necessário ler como hiatos os encontros vocálicos "e-a" e "a-eu", te/ aconselha/ eu (N.E.).
} 
Rebanhando ante si tropel de séculos,

Terá de ir-se engolfar no antigo caos.

Confusos balroando astros com astros

O pego acolherá do céu luzeiros;

$\mathrm{Na}$ terra, que há de abrir seu amplo seio,

Hão de as ondas lutar. A Apolo oposta

De dous corcéis ${ }^{32}$ reger irada a Lua

Por essa obliqua zona, em carro de ébano, ${ }^{33}$

Quererá, como o irmão raiar o dia.

Do orbe estroncado a máquina discorde

Todo o pacto rompeu. Sobre si mesmas

As grandes moles caem. - Tais balizas

De aumento os numes às venturas cravam:

Nem Fortuna outorgou à gente alguma

Contra o povo possante em mar e terra

O impulso desferir da inveja sua.

$\mathrm{Tu}$, do mal todo a causa foste, oh Roma,

De três comum domínio, ${ }^{34}$ liga infausta,

Que o reinado negava a qualquer outro;

Funesto acordo! - Cegos de cúbica, ${ }^{35}$

(Quão sobeja!) que val mesclar as forças,

ter o mundo suspenso e subjugado!

Enquanto o sol, volvendo longas lidas,

Seguir, por signos doze, $\mathrm{e}^{36}$ ao dia a noite

Suster $^{37}$ a terra o mar, a terra os ares,

Nos sócios do reinar, fé não se espere;

Que partilhas o mando não consente.

\footnotetext{
${ }^{32}$ Não quatro como seu irmão.

${ }^{33}$ Nas edições de 1819 e 1838, lê-se évano, possível erro tipográfico (N.E.).

${ }^{34}$ Triunvirato de César, Pompeu e Crasso.

35 "Cnbiça" na edição de 1819 é corrigido por "cubiça" na edição de 1836 . O uso do "u" no lugar do "o" na primeira sílaba da palavra pode ser considerado um latinismo uma vez que a palavra é derivada do termo latino $c$ Vpiditas (N.E.).

36 O acréscimo da conjunção "e" parece inevitável aqui para a retomada da elipse da conjunção "enquanto". No texto latino não se abriu mão das conjunções: Dum terra fretum ... leuabit/ ... et longi uoluent Titana labores/ noxque diem coelo totidem... (N.E.)

${ }^{37}$ Por "sustiver".
} 
Nem anais das nações ${ }^{38}$ abrir releva,

Nem ao longe indagar fatais exemplos:

Nossos primevos muros se orvalharam

Com sangue fraternal; nem foram preço

De furor tanto, então, terras, nem mares:

Tênue asilo empenhou seus dous senhores. ${ }^{39}$

Breve remanso deu discorde aliança; ${ }^{40}$

Nem foi a paz dos capitães arbítrio;

Que só Crasso a enlaçava, posto em meio, ${ }^{41}$

E a guerra a não surgir. - Qual corta as ondas

Istmo estreito e que um mar de outro separa

Nem consente mesclar águas com águas.

Se a terra atrás se encolhe, o Egeu e o Jônio

Se romperão co' as vagas. - Tal, apenas

Com miserando estrago as armas cruas

De ambos os capitães ${ }^{42}$ Crasso atalhando

Manchou c'o Ítalo sangue Assírias Carras: ${ }^{43}$

Desatou logo o Pártico destroço

Os furores Romanos. - Mais vencestes

Do que, Arsácidas, credes. Intestinas

Guerras dais, nessas hostes, aos vencidos.

Talhou a espada os reinos: e a Fortuna

Do povo poderoso que imperava

Em terra e mar, e em toda a redondeza,

Dous não pôde conter: que ${ }^{44}$ a seva destra

Das Parcas retraiu, levou aos manes

\footnotetext{
${ }^{38} \mathrm{Na}$ história grega é mui famosa a guerra de Etéocles e Polinice, filhos de Édipo, sobre o reinar em Tebas; os ódios e horrores dos dous irmãos Atreu e Tiestes, etc., etc.

${ }^{39}$ Rômulo matou a seu irmão Remo, que a par com ele reinava, quando era asilo de facinorosos Roma, $e$ em vez de palácios, se cobria de tugúrios.

${ }^{40}$ Do primeiro triunvirato.

${ }^{41}$ De César e de Pompeu.

${ }^{42}$ Pompeu e César.

${ }^{43} \mathrm{O}$ tradutor mantém número plural que o topônimo Carras, tal como era em latim (N.E.).

${ }^{44} \mathrm{O}$ tradutor por questões de síntese, mas também devido à dificuldade desta passagem (v. 145-9), que oscila entre o tratamento em $2^{\mathrm{a}}$. e $3^{\mathrm{a}}$. pessoas, acaba omitindo o nominativo Iulia presente no texto latino. Essa escolha tradutória resulta em um truncamento de sentido tal que leva o tradutor a lançar mão de três notas de rodapé seguidas (cf. infra notas 40, 41, 42), sendo que a nota 41, a nosso ver, reputa à ignorância dos leitores uma dificuldade de leitura provocada pelo próprio tradutor (N.E.).
} 
Fachos nupciais, ${ }^{45}$ com diro agouro acesos,

Penhor de unido sangue. ${ }^{46}$ - Que se os fados

Te dessem ver do sol mais largos giros,

$\mathrm{Tu}^{47}$ só reter d'aquém teu pai puderas,

E d'além a teu 'sposo enfurecido:

E armadas mãos juntar (depondo lanças),

Qual juntaram, permeiadas, ${ }^{48}$ as Sabinas

Os genros com os sogros. Tu, morrendo,

Soltou-se a aliança, e aos capitães foi dado

(Êmulo esforço os punge!) mover guerra.

$\mathrm{Tu}$, Magno, ${ }^{49}$ temes, que os triunfos novos ${ }^{50}$

Teus antigos eclipsem; que o pirático

Louro, aos vencidos Galos se submeta.

Já te ${ }^{51}$ alça o fio e trato das façanhas,

E a ventura insofrida em grau segundo.

Que César não consente a alguém primeiro,

Nem Pompeu ter igual. - Colher não cabe

Qual dos dous com mais jus vestiu as armas.

Em potente juiz cada um se escora;

A vencedora causa aprouve aos numes;

A vencida a Catão. - Nem correm ambos

Parelhas, na refrega; que à velhice

Vergam já d'um os anos; no remanso

Da toga, longo tempo, em paz, trajada, ${ }^{52}$

Teor de general desaprendera.

Fama anelando, pródigo c'o vulgo,

Só, na aura popular, na voz, que o aplaude

No teatro seu, se embelezava todo:

\footnotetext{
${ }^{45}$ Da filha de César esposada com Pompeu.

${ }^{46}$ Quem não souber a história deste triunvirato, custosamente compreenderá este poema.

47 Júlia, filha de César.

${ }^{48}$ Nas edições de 1819 e 1838, a escolha de "permeiadas" ao invés de "permeadas" tem evidente sabor vulgar (N.E.).

49 Pompeu.

${ }^{50}$ De César.

${ }^{51}$ A César. Aqui, a omissão do vocativo Caesar está presente também no texto latino (N.E.).

${ }^{52}$ Te dá altivez.
} 
Recostado nos seus brasões antigos

Remoçar-se olvidava em vigor novo;

Só do grão nome seu sombras conserva.

Qual sublime carvalho em fértil campo

Blasona o popular despojo antigo

E os sacros dons dos Capitães, no peso,

Não em tenaz raiz o tronco alteia;

Os ramos nus devolve pelos ares; ${ }^{53}$

Não co'as folhas, c'o tronco inda faz sombra:

Bem que aos primeiros sopros do Euro vergue

E queda ameace, e em roda ufanos subam

Ferrenhos bosques, cultos só os tem ele. ${ }^{54}$

Não tinha César, não tal nome e fama ${ }^{55}$

De general, mas tinha inquieto, ativo

Valor, que o ser vencido em campo o anoja;

Onde quer que ambição, vingança o chame

A travar guerra, indômito e ferrenho, ${ }^{56}$

Não poupa a lança, em sangue vai cevá-la:

C'os seus sucessos cerra, insta c'os mimos

Da Fortuna, impelindo quanto lhe obsta

A atingir ao mais alto; e folga abrir-se

Rota, rompendo estragos. - Tal das nuvens,

Com rouco estalo de ar, fracasso do orbe

A violências de Éolo, rompe o raio

Travessa o albor do dia, aterra os povos

Descorados, à face, os olhos lhes deslumbra ${ }^{57}$

Com torti-vaga luz, e solta fúrias

\footnotetext{
${ }^{53}$ O ponto-e-virgula foi acrescentado na edição de 1938 (N.E.).

${ }^{54} \mathrm{O}$ carvalho.

${ }^{55}$ N.E.: O excerto, que vai deste ponto até o final da tradução de Filinto, consta do $1^{\circ}$. volume de Poesia: antologia de poesia universal da Clássicos Jackson, editada por Ary de Mesquita (cf. Filinto Elísio, op. cit., 1950).

${ }_{57}^{56}$ As edições de 1819 e 1838 trazem ponto-final no lugar desta vírgula (N.E.).

${ }^{57}$ Verso alexandrino. A tradução de praestinguens (um equívoco do editor do texto latino já que a forma correta seria praestringens) por "deslumbra" é um bom exemplo da dedicação do tradutor que encontrou um verbo próximo de praestigiae, "prestidigitação, deslumbramento" em exacerbado respeito à letra do original (N.E.).
} 
Contra os seus próprios templos. Nada o estorva;

Ou volte, ou caia, as chamas ele ajunta

Derramadas, quebranta, arruína, arrasa.

A ambos os generais tais causas movem:

Mas são da guerra as públicas sementes

As que sempre afundiram ${ }^{58}$ nações grandes.

Já avassalado o mundo, apenas trouxe

Desmedidas riquezas a Fortuna,

Cederam os usos bons aos usos prósperos, ${ }^{59}$

E inimigos despojos, e rapinas

Luxo inculcaram, desmediram regras

O ouro e edifícios, teve a gula

As mesas dos avós em menoscabo;

De galas, para noiva inda garridas,

Homens se apoderaram. Fogem todos

Da pobreza, em heróis já ${ }^{60}$ tão fecunda.

De todo o orbe acareiam ${ }^{61}$ quanto há sido

De possantes nações fatal destroço:

Remotos marcos, vastas jeiras cingem;

$\mathrm{E}$ as que outrora lavrou com relha dura

Terras Camilo, ou Cúrio abriu co'antigo

Enxadão, dono obscuro encrava ${ }^{62}$ e estende.

Não, com tranqüila paz, contente fora

Tal povo, e com manter com armas quedas

A liberdade sua. De lá vinham

Aceleradas iras; ter por baixa

Maldade a que pobreza a alguns inculca;

E por brasão o que ia à força e ferro;

$\mathrm{E}$ a poder mais que a pátria: era a violência

A vara do direito; eram forçados

\footnotetext{
${ }^{58}$ Variante de "afundaram" (N.E.).

${ }^{59}$ Aos maculosos vícios, que surgiram com a prosperidade.

${ }^{60} \mathrm{~N}$ 'outros tempos.

${ }^{61}$ Nas edições de 1819 e 1838, “acaream" (N.E.).

${ }^{62}$ Nos amplos domínios.
} 
Plebiscitos e leis, como o era tudo:

Foros turbavam cônsules, tribunos;

Em almoeda ${ }^{63}$ as fasces; ${ }^{64}$ que as vendia

A quem mais dava o povo; ao venal Campo, ${ }^{65}$

Combate anual trazendo mortal âmbito ${ }^{66}$

A Roma. Sai de lá voraz usura, ${ }^{67}$

Sôfregos juros, combalido crédito,

E vir, da guerra, grão proveito a muitos.

Já na derrota ${ }^{68}$ os Alpes franqueara

Gelados César, que no peito aloja

Abalos grandes e o guerrear futuro:

Do escasso Rubicon já as abas trilha.

Eis da angustiada Pátria o vulto ingente

Tristíssima no gesto, desparzida,

Desfeito o adorno das madeixas brancas

Na torrígera ${ }^{69}$ fronte, nus os braços,

Radiosa, no obscuro da alta noite,

Se of'rece a César, rompe entre gemidos:

"Onde é que encaminhais? Levais aonde,

Varões, meus estandartes? Té qui parem;

Se vindes cidadãos, se réus não vindes".

\footnotetext{
${ }^{63}$ Para o sentido de "almoeda", cf. nota 61 (N.E.).

${ }^{64}$ O tradutor tem "fasces" por substantivo feminino em português, a despeito da regra geral de empréstimos eruditos em que se emprega o gênero da língua de partida em português, ou seja, "fasces" deveria ser considerado um substantivo masculino (N.E.).

${ }^{65}$ Campo Márcio onde o povo nomeava os cônsules, etc.

66 Âmbito era em Roma chamado todo o empenho de buscar proteções, agradar com lisonjas, com promessas, com dinheiro, etc. a quem dava os cargos. E este crime de âmbito, nocivo ao merecimento e aos bons costumes, era punido pelas leis enquanto elas tiveram vigor. Para mais explicar esta passagem mui difícil para leitores, que não têm notícia da história romana nos últimos tempos da república, ponho aqui os versos de Petrônio: "Emptique Quirites/ ad praedam strepitumque lucri suffragia uertunt./ uenalis populus, uenalis curia Patrum./ est favor in pretio" ["E os Quirites subornados/ fazem das votações um bom negócio,/ vende-se o povo, vende-se o senado./ Todo favor tem preço" (trad. do editor)]. Mais ao claro. Fasces, ou feixes de varas com uma machada nelas embebida, eram insígnias de cônsules, etc. O povo, para esses postos dava os votos, a quem mais dinheiro dava; o que se chama pôr os cargos em almoeda, ou leilão. Para os obter houve, muitas vezes, sanguinolentos arruídos. (N.E.) A citação de Petrônio e algumas das informações presentes na nota foram extraídas do comentário de Grotius \& Farnabius à passagem.

${ }^{67}$ A vírgula é um acréscimo da edição de 1838 (N.E.).

${ }^{68} \mathrm{Na}$ edição de 1819, lê-se "derrora", que é corrigido por "derrota” na edição de 1838 (N.E.). Segundo abonação do Morais, "derrota" é palavra derivada de "rota" e tem aqui o sentido de "caminho, percurso" traduzindo cursu, "percurso, marcha".

69 “Torrígera" é variante do decalque turrígera (N.E.).
} 
Súbito horror embebe a César o ânimo,

Os cabelos, na fronte se lhe eriçam,

Lânguido o passo às ribas ${ }^{70}$ se lhe prende.

Eis se recobra: "Oh Jove, que adoraram,

Em Alba, meus avós; tu que hoje velas

Na rainha do orbe, do alto Capitólio, ${ }^{71}$

E vós troianos deuses tutelares,

Que à Ausônia Enéias trouxe; tu, oh Rômulo,

Que ao Olimpo alçado o nosso culto houveste,

Vesta, a quem na ara é vivo sacro fogo,

Roma, oh tu, que meu númen foste sempre,

Prospera o intento meu. Não venho armado

De furial facho. Terra e mar vencidos, ${ }^{72}$

Ama-o tu, inda é teu: é teu soldado;

E em todo o orbe o será. - Só tem ${ }^{73}$ por crime,

Que inimigo de Roma a César chamem”.

Não difere: co' as tropas rompe o rio. ${ }^{74}$

Leão, que da ardente Líbia em mudos ermos

Avista o caçador, pára e duvida:

Já se anima, recolhe o furor todo, ${ }^{75}$

Ondadas jubas treme, açouta as ancas

Co'a mortífera cauda, ruge irado

Na profunda garganta; e, ou leve $\mathrm{e}^{76}$ o mouro

Lhe arroje o dardo, ou the o zarguncho entranhe,

Golpes transcura, e aos gumes se arremessa.

Tênue ao nascer, desliza tênues ondas

Na estiva, o Rubicon, ardente quadra.

Serpeia em Galo vale, e a Ausônia extrema;

${ }^{70}$ D'aquém de Rubicon.

${ }^{71}$ A vírgula é um acréscimo da edição de 1838 (N.E.).

${ }^{72}$ Havendo César vencido por mar e terra.

${ }^{73}$ N.E.: Nas edições de 1819 e 1838, “dêm”. A correção por tem foi sugerida por Mesquita (Lucano, op. cit., 1950, p. 73).

${ }^{74}$ Rompe o fio que a veia do rio leva.

${ }^{75} \mathrm{Na}$ edição de 1819 consta o verso de 11 sílabas: eis já se anima, recolhe o furor todo, que foi corrigido na edição de 1838 (N.E.).

${ }^{76}$ Leve, por ligeiro. 
Cobra forças no inverno, três chuvosos

Meses o engrossam, fundem neve os Alpes,

E o sopro do Austro $^{77}$ emborca-lhe torrentes.

Para embarrar-lhe o undoso peso, os équites

Lá se impelem, lá travam dique oblíquos:

Suspenso é o curso impetuoso; eis cedem,

E obedientes dão caminho às ondas.

Já César cruza o rio, e poja contra;

Trilha com pé revel vedada a Itália.

"Lá deixo a paz ${ }^{78}$, e as leis que os meus adversos

Hão violado. Oh Fortuna, a ti me entrego:

Seja-me a guerra juiz, árbitro a Sorte”.

\section{Referências Bibliográficas}

BENJAMIN, W. A tarefa-renúncia do tradutor. Tradução de S. K. Lages. In: HEIDERMANN, W. (org.). Clássicos da teoria da tradução. Florianópolis: EDUFSC, 2001. p. 187-215.

CALDAS AULETE. Dicionário contemporâneo da língua portuguesa. $5^{\mathrm{a}}$. ed. Rio de Janeiro: Delta, 1986.

de CASTILHO, A. F. A primavera. 2a . ed. Lisboa: Bulhões, 1837.

FERREIRA, Aurélio B. H. Novo dicionário Aurélio da língua portuguesa. 2.a. ed. Rio de Janeiro: Nova Fronteira, 1997.

FILINTO ELÍSIO. César atravessa o Rúbicon. In: MESQUITA, A. (org.) Poesia. São Paulo: Jackson, 1956. Vol. 1, p. 70-73.

1998. Vol. 1.

Obras completas de Filinto Elísio. Ed. F. Morais. Braga: APPACDM,

GARRETT, A. Lírica completa. Lisboa: Arcádia, 1963.

\footnotetext{
${ }^{77}$ As melhores edições, a de Grotius \& Farnabius inclusive, trazem Euro. A escolha de Austro é uma correção que Lemaire (Lucanus, op. cit., 1830, p. 120) atribui a Schraderus. Este dado singular faz pensar na possibilidade de que Filinto tivesse consultado outras edições além de Grotius \& Farnabius (N.E.).

${ }^{78}$ Diz César.
} 
HOUAISS, A \& VILLAR, M. de S. Dicionário Houaiss da língua portuguesa. Rio de Janeiro: Objetiva, 2001.

LUCANUS. De bello ciuili. Cum Hug. Grotii, Farnabii notis integris et uariorum selectissimis. Londini: J.F. Dove, 1818.

Pharsalia, de Marco Aenio Lucano. In: Obras completas de Filinto Elysio. Paris: Bobée, 1819. Vol. 11, p. 60-73.

Pharsalia, de Marco Aenio Lucano. In: Obras de Filinto Elysio. Lisboa: Tipographia Rollandiana, 1838. Vol. 10, p. 234-251.

Pharsalia: cum uarietate lectionum. Volumen prius, argumentis et selectis uariorum adnotationibus quibus suas addidit Petrus-Augustus Lemaire. Parissiis: colligebat n.e. Lemaire, 1830 (disponível em <http://gallica.bnf.fr> acesso em 05 jan. 2002).

SARAIVA, A. J.; LOPES, O. História da literatura portuguesa. 15ª ed. Porto: Porto Editora, 1989.

MENDES, Manuel Odorico. Virgilio Brazileiro ou traducção do poeta latino por Manuel Odorico Mendes. Paris: Typographia de W. Remquet, 1858.

VIEIRA, B. V. G. "Farsália”, de Lucano, cantos I a IV: prefácio, tradução e notas. Tese de doutorado em Estudos Literários apresentada à Faculdade de Ciências e Letras da UNESP de Araraquara. Araraquara: UNESP, 2007. 